\title{
AdindaMass
}

Volume 1 Nomor 2, Januari 2022

DOI: https://doi.org/10.37726/adindamas.v1i2.324

\section{PKM Pemberdayaan Ibu-ibu Rumah Tangga Melalui Pelatihan Limbah Bernilai Ekonomis di Rumah Kemasan Kabupaten Purwakarta}

\author{
Ahmad Saepudin ${ }^{1}$, Riski Siti Nurjanah², Jalaludin ${ }^{3}$ \\ 1,3 Sekolah Tinggi Ilmu Ekonomi Syariah (STIES) Indonesia Purwakarta \\ Jln. Veteran No. 150-152 Ciseureuh Purwakarta, Jawa Barat Indonesia \\ 1ahmadsaepudin899@yahoo.com \\ 3jalaludin@gmail.com \\ 2Sekolah Tinggi Ilmu Ekonomi Syariah (STIES) Indonesia Purwakarta \\ Jln. Veteran No. 150-152 Ciseureuh Purwakarta, Jawa Barat Indonesia \\ 2riskisitinurjanah@gmail.com
}

\begin{abstract}
ABSTRAK
PKM merupakan bagian dari aktivitas kegiatan kelompok PKK yang dipelopori dari organisasi penggerak Ibu-ibu Rumah tangga dalam pemberdayaan limbah sebagai nilai aset perekonomian di Kabupaten Purwakarta. Penanganan limbah menjadikan sorotan terpenting bagi masyarakat yang berpengaruh pada kesehatan dan kebersihan lingkungan. Selain menjadi bagian dari ketidak nyaman di lingkungan Purwakarta. Limbah juga diperdayakan sebagai bagian dari nilai ekonomis, sehingga kemanfaatan tidak hanya dari satu sudut aspek kesehatan dan kebersihan saja melainkan harus menjadi nilai ekonomis bagi kesejahteraan Ibu-ibu Rumah Tangga di Purwakarta. Penanganan limbah sudah barang tentu menjadi program utama dari pemerintah melalui program pemungutan limbah yang dicanangkan oleh kementerian Lingkungan Hidup dan Kehutanan sejak Tahun 2015, dengan tujuan mengurangi jumlah limbah yang ada di sekitar area lingkungan perjalanan. Hal ini, menjadi sangat penting bagi kelompok PKK untuk menggerakkan ibu-ibu sebagai bagian dari memanfaatkan limbah menjadi nilai ekonomis. Adanya permasalahan tersebut tertarik untuk memberikan solusi dengan meningkatkan pemberdayaan penyuluhan pelatihan nilai ekonomis terhadapnya adanya limbah di Kabupaten Purwakarta. Tahapan penelitian ini dengan secara langsung terjun kelapangan dan
\end{abstract}


wawancara kepada bagian organisasi PKK dan memberikan analisis dengan referensi yang berkaitan dengan penanganan limbah dan limbah sebagai nilai ekonomis. Metode kegiatan yang akan dilaksanakan dalam kegiatan ini dengan cara bimbingan sosial kelompok dan pengembangan masyarakat lokal, teknik yang digunakan dengan cara dijelaskan dalam bentuk seminar kemudian pelatihan secara seksama. Dengan demikian dapat menghasilkan nilai-nilai ekonomis pada pengelolaan limbah yang ada di Kabupaten Purwakarta.

Kata kunci : PKM, Pelatihan, PKK, Limbah dan Ekonomis

\section{ABSTRACT}

PKM is part of the activities of the PKK group which was pioneered by the organization that drives housewives in empowering waste as an economic asset value in Purwakarta Regency. Waste management is the most important focus for the community, which affects health and environmental hygiene. Besides being part of the discomfort in the Purwakarta environment. Waste is also exploited as part of the economic value, so that the benefits are not only from a health and hygiene aspect, but must be an economic value for the welfare of Housewives in Purwakarta. Waste management is of course the main program of the government through the waste collection program launched by the Ministry of Environment and Forestry since 2015, with the aim of reducing the amount of waste around the travel environment. This becomes very important for the PKK group to mobilize women as part of utilizing waste into economic value. The existence of these problems is interested in providing solutions by increasing the empowerment of economic value training counselling for the presence of waste in Purwakarta Regency. The stage of this research is to directly go into the field and interview the PKK organizational section and provide an analysis with references related to the handling of waste and waste as an economic value. The method of activities that will be carried out in this activity is by means of group social guidance and local community development, the techniques used are explained in the form of seminars and then training carefully. Thus, it can produce economic values in waste management in Purwakarta Regency.

Keywords: PKM, Training, PKK, Waste and Economical

\section{PENDAHULUAN}

Limbah adalah bahan dari yang sudah di buang tidak terpakai yang memberikan dampak negatif bagi masyarakat jika tidak diperhatikan dan dikelola dengan baik. Limbah bagian dari sisa-sisa produksi, baik dari alam maupun hasil kegiatan manusia. Hal ini juga sudah tercantum pada Kepurusan Menperindag RI No. 231/MPP/Kep/7/1997 Pasal I tentang prosedur impor limbah, menyebutkan bahwa limbah adalah barang atau bahan sisa dan bekas dari kegiatan atau proses produksi yang fungsinya sudah berubah. Lalu, berdasarkan Peraturan Pemerintah No. 18/1999 Jo.PP 85/1999, limbah didefinisikan sebagai sisa atau buangan dari suatu usaha dan

ADINDAMAS (Jurnal Pengabdian Kepada Masyarakat), Volume 1, Nomor 2, Januari 2022 http://journal.sties-purwakarta.ac.id/index.php/adindamas/ ISSN: 2798-2874 (Media Online) 2798-4702 (Media Cetak) 
atau kegiatan manusia. Dengan kata lain, limbah adalah barang sisa dari suatu kegiatan yang sudah tidak bermanfaat atau bernilai ekonomi lagi. ${ }^{1}$

Limbah bisa buangan dari berbentuk plastik, yang produksi industri banyak digunakan kemanfaatan bagi kebutuhan rumah tangga. Plastik cukup banyak dgunakan sebagain bagian dari kebutuhan hidup; seperti pembungkus makanan, kemasan air mineral, perabot rumah tangga dan plastik kersek. Dibalik banyaknya kemanfaatan tersimpan juga adanya banyak bahaya yang besar bagi lingkungan dan kesehatan. Plastik yang sudah tidka teruraikan secara biologis, melainakan oleh foton (partikel elektromagnetik). Upaya yang tidak dibolehkan dengan cara pengelolaan limbah plastik dengan cara pembakaran yang tentunya akan menyebabkan polusi udara. $^{2}$

Sejak diluncurkannya peraturan dari Mentri Negeri Lingkungan Hidup Republik Indonesia Nomor 13 Tahun 2012 tentang pedoman pelaksanaan reduce, reuse dan recycle, pemerintah Daerah Kabupaten Purwakarta turut meresponnya dengan berbagai kegiatan. Termasuk adanya penanganan limbah menjadi bagian dari sebagai penghasilan ekonomi bagi warga masyarakat Purwakarta. Untuk mewujudkannya diperlukan partisipasi masyarakat, sebagainana termuat dalam Undang-Undang RI No. 18 Tahun 2008 tentang Pengelolaan Sampah, dimana menurut Pasal 28 Ayat 1 Undang-undang RI No. 18 Tahun 2008 tentang Pengelolaan Sampah, "masyarakat dapat berperan serta dalam pengelolaan sampah yang diselenggarakan Pemerintah dan/atau pemerintah daerah." itu artinya bahwa partisipasi masyarakat dalam pengelolaan sampah sangat dibutuhkan demi terwujudnya lingkungan yang baik sehat, bersih dan rapi. ${ }^{3}$

Dalam pengelolaan limbah, seperti yang sudah dijelaskan sebelumnya dari pemberdayaan industri ramah lingkungan mellaui program CSR di Kabupaten Purwakarta dalam rangka pengelolaan limbah B3 dihubungkan dengan UU No. 40 Tahun 2007 tentang PT Jo. UU No. 32 Tahun 2009 tentang perlindungan pengelolaan lingkungan Hidup. Dari jurnal ini mereka menghasilkan sebagai sebuah aturan secara hukum yang melihat dari aspek negatifnya dari dampak polusi yang mengerikan pada kehidupan lingkungan masyarakat yang dapat merusak ekosistem. ${ }^{4}$

Partisipasi masyarakat dalam pengelolaan limbah dapat meningkatkan kesadaran masyarakat akan pentingnya nilai ekonomis serta menampung aspirasi

1 (https://www.detik.com/edu/detikpedia/d-5538767/pengertian-limbah-karakteristik-dan-jenisjenisnya). Akses 2019.

2 Meliandi Purwandito, Eka Mutia dan Ellida Novita Lydia, Pelatihan Pemanfaatan Limbah Plastik Menjadi Produk Bernilai Ekonomis Pada Desa Keumuning Peut. Vol 2 No 2 (2020): Global Science Society (GSS) Jurnal Ilmiah Pengabdian Kepada Masyaraka

${ }^{3}$ Riany L Nurwulan, dkk, PKM Pemberdayaan Kelompok Pkk Melalui Program Pengelolaan Sampah di Desa Wanayasa Kecamatan Wanayasa Kabupaten Purwakarta, Joernal Universitas Pasundan.

${ }^{4}$ Fakultas Hukum, UNPAS, Pemberdayaan Industri Ramah Lingkungan Melalui Program CSR DI Kabupaten Purwakarta dalam Rangka Pengelolaan Limbah B3 Dihubungkan dengan UU No. 40 Tahun 2007, Tentang PT. Jo. UU no. 32 Tahun 2009 Tentang Perlindungan dan Penglolaan Lingkungan Hidup. Hukum Perdata, 2018.

ADINDAMAS (Jurnal Pengabdian Kepada Masyarakat), Volume 1, Nomor 2, Januari 2022 http://journal.sties-purwakarta.ac.id/index.php/adindamas/

ISSN: 2798-2874 (Media Online) 2798-4702 (Media Cetak) 
dari kreatifitas masyarakat Kabupaten Purwakarta. Selain itu diadakannya pelatihan ini, meningkatkan kualitas dari perekonomian yang memanfaatkan nilai kemaslahatan kebersihan lingkungan. Hal ini menjadi bagian dari terpentingnya sebagian dari keimanan sesorang dalam mengelola limbah dengan cara asas kemanfaatan bagi keberesihan termasuk bagi nilai-nilai ekonomis. Berbagai program adanya pelatihan ini supaya mampu mengelola limbah dari berbagai produksi yang sudah tidak terpakai kemudian ditingkatkan pada kemanfaatan untuk kesejahteraan masyarakat lokal.

Ekonomi Islam yang merupakan dari suatu pemahaman yang berupaya merealisasikan kebahagian hidup manusia melalui alokasi dna distribusi sumberdaya terus berada pada ajaran Islam tanpa mengekang kebebasan individu dalam menciptakan keseimbangan ekonomi ekologi sebagai yang berkesinambungan satu sama lainnya. ${ }^{5}$ Sistem ekonomi Islam dalam memandang masalah ekonomi tidak melihat pada sudut kapasitas yang memberikan kebebasan, hak pemilikan kepada individu serta menggalakan usaha secara perorangan, tidak pula dari sudut pandangan sosialis dengan menghapus emua hak individu dan menjadikan masyarakat seperti budak ekonomi yang dikendalikan oleh negara. Islam sangat membolehkan untuk memperhatikan kepentingan pribadi dengan tidak mmebiarkan merusak pada tatanan kehidupan masyarakat, Untuk itu, pelaksanaansistem ekonomi Islam dapat diperaktikan sehari-hari dalam mengorganisasikan faktor produksi, distribusi ataupun memanfaatkan barang dan jasa yang dihasilkan dengan tidak menyalahi Alqur'an dan Hadits sebagai pedoman dan panduan sistem ekonomi Islam. ${ }^{6}$ Islam juga menilai dari sistem cara pengambilan dan pengelolaan hasil dari limbah selain dari asas pemanfaatan dan keberlangsungan penjagaan ekologi.

Pelatihan ini, melihat adanya kondisi di lingkungan masyarakat yang banyaknya limbah poduksi yang tidak dimanfaatkan secara nilai ekonomis dan bagaimana pemanfaatan nilai ekonomis secara pandangan Islam. Adanya pelatihan ini memberikan nilai akademisi secara kajian ekonomi bagi lingkungan organisasi PKK yang melibatkan Ibu-ibu Rumah Tangga. Kebutuhan pelatihan ini, didasarkan karena sangat jarang yang memperdayakan PKM pemberdayaan Ibu-ibu Rumah Tangga terhadap limbah yang dijadikan nilai ekonomis sebagai penunjang kebutuhan finansial masyarakat. Pelatihan ini yang memperdayakan juga mahasiswa STIES Indonesia Purwakarta sebagai bentuk dari pengabdian pada masyarakat yang di bmbing oleh Dosen secara langsung. Pelatihan ini hanya beberapa pertemuan dan dilanjut dengan secara pembagian geroup.

${ }^{5}$ Rahman, Afzalur, Economic Doctrines of Islam, Terj. Soeroyo Nastangin, "Doktrin Ekonomi Islam", Jilid 2, (Yogyakarta: Dana Bhakti Wakaf, 1995), 10.

${ }^{6}$ Lubis, Suhrawardi K, Hukum Ekonomi Islam, Cet. 1, (Jakarta: Sinar Grafika, 2000), 14.

ADINDAMAS (Jurnal Pengabdian Kepada Masyarakat), Volume 1, Nomor 2, Januari 2022 http://journal.sties-purwakarta.ac.id/index.php/adindamas/ ISSN: 2798-2874 (Media Online) 2798-4702 (Media Cetak) 


\section{METODE}

Kegiatan pemberdayaan ini dilaksanakan pada tanggal 11 Februari - 24 Februari 2019. Tahapan penelitian ini dengan secara langsung terjun kelapangan dan wawancara yang dilakukan oleh Mahasisiwa kepada bagian organisasi PKK untuk meminta kesiapan hadir mengikuti pelatihan yang akan dilaksanakan oleh dosen dan mahasisiwa STIES Indoneisa Purwakarta dan memberikan analisis dengan referensi yang berkaitan dengan pemanfaatan limbah dan nilai ekonomis terhadap pemanfaatan limbah dalam analisis Islam. Metode kegiatan yang akan dilaksanakan dalam kegiatan ini pada pengabdian masyarakat, analisis yang diperdalam sebagai deskriptif untuk mengkaji PKM Pemberdayaan Ibu-ibu Rumah Tangga Melalui Pelatihan Limbah Bernilai Ekonomis di Rumah Kemasan Kabupaten Purwakarta. Dalam proses analisisnya hanya pada bagian sisi nilai ekonomis secara Islam yang mengambil dari pemanfaatan limbah, dengan cara observasi, wawancara dan pengambilan referensi. Adapun secara berkelanjutan pelatihan dengan cara melibatkan bantuan mahasiswa dengan cara bimbingan sosial kelompok dan pengembangan masyarakat lokal, teknik yang digunakan dengan cara dijelaskan dalam bentuk seminar kemudian pelatihan secara seksama.

\section{A. Gambaran Umum}

\section{HASIL DAN PEMBAHASAN}

Limbah yang berada di lokasi Purwakarta menurut mantan Wakil Bupati Dedi Mulyadi, yang menjadi persoalan besar terhadap pencemaran kondisi lingkungan dan air disekitar lingkungan masyarakat menjadi curah dari tidak adanya koordinasi antara perusahaan kecil yang terhadap pemerintah setempat. Selain itu adanya pembuangan sampah yang masih berserakan di lokasi-lokasi pinggir jalan sebagai arus jalannya air. Selanjutnya dengan banyaknya pabrik-pabrik juga, tentu mengakibatkan polusi lingkungan yang menjadi sorotan bagi masyarakat disekitarnya. ${ }^{7}$

Limbah juga dapat dikeluarkan dari Rumah sakit, seperti bekas alat suntik, bekas plastik obat-obat, bungkus obat dan bekas impusan. Kemudian limbah dari prabot Rumah tangga, limbah dari pedagang kaki lima dan pasar-pasar yang berbentuk plastik, bekas minuman, bekas kopi, bekas roko dan lain sebagainya. Sebagai bagian dari tanggung jawab para akademisi hal ini menjadi kewajiban untuk memberikan partisifasi sedikitnya untuk memberikan solusi terhadap ekologi lingkungan dan secara ekonomis.

Sebagaimana diatas sudah dijelaskan di pendahuluan limbah merupakan sisa yang dibuang yang tidak bisa dipakai kembali oleh orang yang memilikinya. Apakah

${ }^{7}$ Artikel ini sudah Terbit di AyoPurwakarta.com, dengan Judul Dedi Mulyadi Ingin Pelopori Persoalan Pencemaran Lingkungan, pada URL https://www.ayopurwakarta.com/read/2019/11/29/3689/dedimulyadi-ingin-pelopori-persoalan-pencemaran-lingkungan. 2019.

ADINDAMAS (Jurnal Pengabdian Kepada Masyarakat), Volume 1, Nomor 2, Januari 2022 http://journal.sties-purwakarta.ac.id/index.php/adindamas/ ISSN: 2798-2874 (Media Online) 2798-4702 (Media Cetak) 
dasar dari membuang secara sembarangan atau membuang pada tempat yang sudah disediakan oleh pemerintah setempat dan pemilik rumah, bahkan bisa jadi limbah pabrik dalam proses genangan air akibat saluran yang tidak dibereskan. Berdasarkan kesesuaian yang ada dilingkungan sekitar Purwakarta. Maka, pelatihan ini, ingin mencoba memanfaatkan hasil dari limbah menjadi daya manfaat secara lingkungan ekologi, keberesihan terutama secara ekonomis. Pelatihan ini disekitar lingkungan masyarakat Rumah kemasan di Kabupaten Purwakarta. Lokasi ini masyarakat yang sudah sedikitnya berjalan tentang pemanfaatan kerajinan dari limbah, tetapi nilai ekonomis kurang dapat diperdayakan. Sehingga dengan adanya mahasisiwa dan dosen yang terjun langsung pada lokasi, sebagai solusi nilai ekonomis.

\section{B. Proses Pemanfaatan Limbah}

Limbah keras dapat diperoses secara dipilih berdasarkan keriteria, bahan mana yang terpakai dan bahan mana yang sekiranya sulit untuk dimanfaatkan, sehingga dalam peroses pemanfaatan secara ekonomis juga harus memahami antara sampah organik dan anorganik, supaya mempermudah perose dalam pemilihan dan perose secara pemanfaatan yang akan menjadi nilai ekonomis. Proses limbah yang berasal dari tempat pembuangan sampah atau yang berserakan sudah lama dalam pemerosesan limbah keras, biasanya sudah terkontambinasi oleh bakteri yang akan mengandung penyakit. Oleh karena itu limbah seprti ini harus di cucu dan dihilangkan dulu kuman yang menempel baik dengan sabun atau cairan disinfeksan. Setelah dicuci limbah tersebut harus dikeringkan secara sempurna.

Proses daur ulang dapat dimanfaatkan sebagai bentuk kerajinan, seperti mengubah kaleng bekas menjadi tempat pensil, bungkus kopi yang dapat dijadikan berbagai macam tas, dompet bahkan dapat dijadikan karpek. Begitu juga libah dari botol-botol bisa sebagai wadah ikan hiasan dan bisa dijadikan hiasan pagar rumah. Proses ini memang tidak mudah perlu adanya waktu yang intens. Bahkan bisa juga dengan adanya proses pengecetan atau pemberian aksesoris agar menjadi unik dan menarik. Proses ini tentu harus diperhatikan keamanan dan kesehatan bagi masyarakat apalagi proses yang akan diperjual belikan. Keratif dari hasil limbah dapat dijadikan pula sebagai nilai lomba fashion show dari bahan limbah plastik kemasan dan menggelar filem pendek sebagai alat seni yang ditampilkanya hasil dari limbah.

\section{Nilai Kreatif / Ekonomis}

1. Limbah Air

Limbah air yang biasa menjadi kocoran air di sekitar lingkungan bisa menjadi bahan pupuk untuk tanaman. Proses pengambilan ini tentu tidak hanya sebatas air yang hitam yang diambil akan tetapi air yang bercampur tanah yang sudah melendir kemudian di simpan beberapa hari sampai tanah agak kering kemudian bisa di bungkus pakai plastik ukuran tergantung kebutuhan. 
2. Limbah Plastik

a. Limbah plastik menjadi tas

Limbah plastik akan dapat berguna dan menjadi nilai ekonomis, manakala bahwa harus bisa memperoses pada bentuk kerajinan seperti dibikinnya tas untuk berbagai kalangan, memang proses imajinasi seni harus ada bagi orang yang ingin betul-betul memanfaatkan peluang ini. Pemanfaatan seperti tas, barang-barang rumah tangga yang lainnya,

b. Mengubah botol menjadi alat Tulis

Plastik dalam bentuk botol juga bisa menjadi manfaat dan nilai ekonomis, tergantung dari masyarakat yang memanfaatkannya, maka dari itu palstik botol dapat dimanfaatkan sebagai bahan alat tulis yang dihias dengan pernik lainnya supaya daya tarik pembeli tersebut banyak,

c. Sebagai Hiasan Pot Bunga

Botol seperti bekas minuman soda, susu, jus dan minuman lainnya, bisa dijadikan sebagai alat untuk wadah ikan hias, sebagai pot bunga omprovisasi. Pilihlah botol besar untuk pot bunga, buatlah lubang dengan ukuran sesuai ukuran, kemudian masukan tanah dan jangan lupa pakai lubang kecil dibawah untuk proses keluar air siram,

d. Sebagai Tutup Tanaman yang masih Kecil

Proses ini masih dalam pemanfaatan dari plastik botol seperti bekas aqua, soda dan lain sebagainya, proses ini menjadi nama membuat rumah kaca untuk sayuran. Dalam prose kaca konvensional tentu akan memakan biyaya yang banyak dan menepati ruangan sama-sama untuk sementara dalam proses pertumbuhan dalam beberapa hari. Cara pemerosesannya potong bagian bawah botol PET, buka tutupnya, dan letakkan di tempat tidur taman Anda sehingga botol mengelilingi tanaman. Rumah kaca improvisasi ini terlihat sederhana, tetapi akan memperpanjang musim panas untuk sayuran Anda dan melindunginya dari angin.

e. Sebagai alat untu menyiram tanaman dan bunga

Cara mengolah limbah plastik botol ini juga dapat dimanfaatkan sebagai pemanfaatan alat siraman bunga dan tanaman. Ada dua proses cara ini, bisa dilakukan dengan menggali lubang pada pinggir tanaman yang sudah diberi lubang dan bisa juga menggunakan alat pegangan yang mana botol tersebut sudah dirapihkan dikasih lubang, gunanya agara air merambas dan mengalir dengan tidak boros.

3. Limbah Kaleng

Recycle pada kaleng setelah kaleng proses pembersihan, kemudian kaleng dipotong secara kecil-kecil dengan mesin sehingga terlepas dari bagian luar pewarna atau lebelnya. Kemudian kaleng dipanaskan pada suhu tinggi, agar logam penyusunannya melelh. Logam dalam kaleng berbentuk almunium. Kaleng bisa dimanfaatkan dengan berbagai kreasi bagi kebutuhan masyarakat. 
Melihat banyaknya limbah kayu dalam sudut pandang ekonomi mikro dapat dimanfaatkan sebagai nilai ekonomis yang membantu kebutuhan hidup sehari-hari sehingga limbah kayu dapat dimanfaatkan untuk rak sepatu, rak baju dan mainan mobil buat anak-anak. Secara pemasaran dari awalnya memang cukup sulit. Selain itu, limbah dari botol dan bekas kopi dapat dimanfaatkan sebagai bagian dari seni wayang golek.

\section{Analisis Nilai Ekonomis Pada Pemanfaatan Limbah}

Sesuai hasil observasi dan wawancara limbah air, hasil buangan yang berserakan di sekitar daerah Purwakarta. Menjadi PR besar bagi para akademisi yang tentu STIES Indonesia Purwakarta menjadi salah satu pelopor baik dari dosen dan mahasisiwa untuk memanfaatkan limbah sebagai bagian dari nilai ekonomis yang mampu membantu bagi sumber daya finansial bagi masyarakat kecil. Pelatihan ini dengan secara langsung menghadirkan bagian dari pakar lingkungan masyarakat dan dosen STIES Indonesia Purwakarta beserta mahasisiwa sebagai bagian dari pelatihan nilai ekonomis yang harus dimanfaatkan sekecil apapun. Mahasiswa yang sudah dibekali nilai-nilai mata kuliah ekonomi mampu memberikan rangsangan bagi masyarakat untuk bisa mengembangkan secara nilai nominal bentuk materi. Sampah bisa bernilai ekonomi apabila dikelola dengan bijak dan baik dan melibatkan semua elemen termasuk para pengkaji ekonomi. Limbah tidak hanya dikumpulkan saja, diangkut lalu dibuang ketempat pembuangan "TPA" yang tidak memiliki nilai ekonomis sekali. Namun kini, mahasiiswa sangat peduli bagi tatanan masyarakat untuk mempertahankan hidupnya dari hasil pemanfaatan limbah tersebut.

Pola pemikiran ini, memang dimuncuklan bagi pelaku-pelaku masyarakat atau mahasisiwa yang kreatif dan terutama yang ekonomis dalam nilai kesederhanaan. Limbah jangan hanya diangkut dan dibuang saja, akan tetapi harus menjadi bagian motor penggerak ekonomi bagi kehidupan masyarakat. Sesuai yang sudah diatur oleh presiden Nomor 97 Tahun 2017 tentang kebijakan dan strategi Nasional dalam pengelolaan sampah atau yang termasuk didalamnya limbah Rumah Tangga. ${ }^{8}$ Pemanfaatan limbah dengan daya nilai ekonomis yang cukup kuat bagi masyarakat. Limbah di Purwakarta mampu menjadi estimasi nilai ekonomis yang besar bila masyarakat terutama Ibu-ibu yang hanya diam di rumah yang tidak biasa memanfaatkan yang ada akan keluar banyak uang dibadning menghasilkan. Jika limbah dari non-organik per tahun mencapai total ekonomi yang sangat banyak.

Dalam teori ekonomi terdapat bagian yang dikembangkan usaha masyarakat kecil, terutama hasil dari ekonomi yang dimunculkan dari kekeretifan masyarakat hasil dari olehan limbah. Dalam kajian ilmu ekonomi mikro bagian dari sifat menganlisis bagian kecil dari keseluruhan kegiatan perekonomian. Dalam kafasitas ekonomi mikro bagaimana masyarakat mampu menggunakan faktor produkasi yang

${ }^{8}$ https://mediaindonesia.com/humaniora/248591/manfaatkan-nilai-ekonomi-di-balik-sampah. 2018.

ADINDAMAS (Jurnal Pengabdian Kepada Masyarakat), Volume 1, Nomor 2, Januari 2022 http://journal.sties-purwakarta.ac.id/index.php/adindamas/ ISSN: 2798-2874 (Media Online) 2798-4702 (Media Cetak) 
ada secara efesien supaya kemakmuran masyarakat dapat dimaksimalkan. Ekonomi mikro dalam kancah pemanfaatan sumber dari limbah dalam sudut ekonomi merupakan bagian dari cabang nilai yang sangat ekonomis dan menimbulkan prilaku individu baik konsumen dan perusahaan serta melihat harga pasar dan kuantitas input, barang juasa yang dipasarkan. Ekonomi mikro biasanya melihat dari bagaimana cara menentukan penawaran dan permintaan atas barang dan jasa yang disediakannya. ${ }^{9}$

Limbah merupakan bagian barang-barang yang sudah tidak dipakai, akan tetapi bisa dimanfaatkan untuk keperluan hidup manusia sehingga dapat dihasilkan pada produktifitas ekonomi kreatif bagi masyarakat. Sesuai dengan kreativitas dari limbah yang diprktikan sebagian masyarakat Purwakarta. Ekonomi kreatif biasanya mengambil hasil dari jasa masyarakat yang memiliki kekeratifan yang bisa menghasilkan nilai mata uang. Ekonomi kreatif menjadi bagian dari usaha industri yang dilakukan masyarakat dengan mengembangkan situasi kondisi atau memanfaatkan barang-barang yang tidak dihasilkan dengan nilai nominal yang tinggi akan tetapi dapat menghasilkan nilai ekonomis yang maksimal. Ekonomi kreatif dapat meningkatkan angka pendapatan daerah setempat dan dapat meningkatkan nilai ekonomis bisnis individu dalam prilaku bisnis produk maupun jasa ekonomi kreatif. Dengan tentu modal yang tidak terlalu banyak, masih dapat dilakukan secara efektif dan efesien dengan hasil yang baik.

Jumlah penduduk Indonesia jika dianalisa tidak hanya pendudukan Purwakrta saja, jumlah produk barang dapat meningkatkan untuk mencukupi keburuhan sehari-hari. Pelatihan ini sengaja dengan cara menggungah Ibu-ibu Rumah Tangga untuk menghasilkan nilai materi secara baik meskipun dengan modal yang sedikit. Tidak hanya pemanfaatan limbah saja. Kalau sudah mengenal dengan sedikitnya konsep ekonomis akan mendafatkan suatu keingan yang baik. ${ }^{10}$

Ekonomi kreatif mampu memanfaatkan hasil dari produk tidak ramah lingkungan, sehingga dengan pengelolaan ekonomi kreatif dapat dimanfaatkan supaya tidak terjadi arus bahaya pada lingkungan. Sehingga proses ini kalau tidak dimanfaatkan akan timbul bahaya bajir, longsor, kebakaran hutan, dan genangan pada setiap rumah. Solusi ini tentu memberikan ajas kemanfaatan bagi masyarakat terutama di lingkungan masayarakat Purwakarta. Ekonomi kreatif menjadikan bagian bagi masyarakat tergerak untuk memberikan penyuluhan tentang limbah yang bisa dimanfaatkan sebagai wujud dari kreatifitas masyarakat dalam membantu penganan limbah juga harapan sebagai emplimintasi dari langkah menumbuhkan ekonomi kreatif dikalangan masyarakat. Sebagaimana dengan cara memanfaatkan limbah-limbah yang sudah dijelaskan diatas selain sebagai solusi ekonomi juga sebagai solusi lingkungan.

${ }_{9}^{9}$ Syafaatul Hidayati, Teori Ekonomi Mikro, (Banten: Universitas Pamulang, UNPAM Press, 2019$), 9$.

10 https://gc.ukm.ugm.ac.id/2018/11/ekonomi-kreatif-pemanfaatan-barang-bekas/.UGM, 2018.

ADINDAMAS (Jurnal Pengabdian Kepada Masyarakat), Volume 1, Nomor 2, Januari 2022 http://journal.sties-purwakarta.ac.id/index.php/adindamas/

ISSN: 2798-2874 (Media Online) 2798-4702 (Media Cetak) 
Industri kreatif menurut Mulyono Maulid adalah adalah industri yang mengandalkan pada keaslian kreativitas, keterampilan dan talenta individu yang memiliki kemampuan meningkatkan taraf hidup dan penciptaan kesempatan kerja melalui eksploitasi hak kekayaan intelektual.11

36 Industri kreatif di Indonesia tumbuh dan berkembang menjadi basis baru disektor industri. Industri kreatif tumbuh hampir semua lapisan ekonomi dari yang mulai skala besar, menengah, maupun kecil. Industri kreatif memiliki keunikan, dimana sebagian besar ditopang oleh factor social, budaya bangsa, kearifan local, kelestarian lingkungan, dan keunikan lainnya yang digabungkan dengan ilmu pengetahuan dan teknologi sehingga industry ini mendapatkan pasar yang cukup luas dimasyarakat Indonesia dan bahkan banyak produk-produk dari industri kreatif Indonesia yang di ekspor keluar negeri.

Sifat konsumtif bagi masyarakat memang sudah terpolakan dengan cara gaya hidup, tetapi kemanfaatan akan keindahan masyarakat selalu ada, bahkan banyak. Maka dari itu, limbah yang dimanfaatkan dan menjadi konsumsi hiasan masyarakat kota dengan nilai ekonomis yang maskimal. Kalangan masyarakat ini memiliki tingkat dan kualitas pendidikan yang tinggi, sehingga mereka memiliki kesempatan lebih besar dalam mendapatkan pekerjaan dengan penghasilan yang tinggi pula. Dengan penghasilan tinggi, kalangan ini menjadi segmen konsumen yang paling berdaya di pasar. Mereka cenderung mengkonsumsi tak hanya untuk memenuhi kebutuhan harian, namun juga untuk merayakan gaya hidup dan status sosial. Mereka membeli barang-barang mewah, berwisata ke luar negeri, maupun mengenyam pendidikan di universitas-universitas ternama. Hal ini, sebagai asas kemanfaatan bagi masyarakat yang cukup kreatif yang mampu menghasilkan ekonomi diatas gemerlapnya gaya hidup masyarakat saat ini.

\section{E. Pemanfaatan Limbah dalam Sudut Pandang Ekonomi Syariah}

Dalam ajaran agama Islam telah menjelaskan dan memberikan peluang usaha untuk bisnis yang seluas-luasnya kepada pemeluknya atau masyarakat. Islam memiliki landasan konseptual dan nilai teoritis serta praktis dalam sistem ekonomi secara syariah. Bisinis di dalam Islam telah ditentukan hukumnya, halal dan haram pada suatu bisnis. Bisnis sangat diperbolehkan yang dapat menghasilkan pendapatan yang halal dan berkah tidak merugikan sebagian masyarakat. Rasulullah diutus oleh Allah SWT untuk menghapus segala sesuatu yang kotor, keji, gagasan dan karyakarya yang memandharatkan. ${ }^{12}$

Berdasarkan telaah nilai ekonomis pada pemanfaatan limbah. Peneliti melihat asas memanfaatkan nilai-nilai yang akan merusak lingkungan dan diambil sebagai kreatifitas kerajinan tangan yang dimabil sebagai bagian dari jasa upah dari proses

11 Mulyono Maulid, Menggerakan Ekonomi Kreatif Antara Tuntunan Dan Kebutuhan, (Jakarta: Rajawali Pres, 2010), 81-86 36.

12 Ali Hasan, Manajemen Bisnis Syari'ah, (Yogyakarta: Pustaka Pelajar, 2009), 196.

ADINDAMAS (Jurnal Pengabdian Kepada Masyarakat), Volume 1, Nomor 2, Januari 2022 http://journal.sties-purwakarta.ac.id/index.php/adindamas/ ISSN: 2798-2874 (Media Online) 2798-4702 (Media Cetak) 
tersebut. Adapun barang yang diambil dan diproses untuk dijadikan nilai ekonomis itu, barang yang dimana yang sudah dibuang dan dimanfaatkan tentu bukan barang curian. Terkecuali proses pengambilan tanpa sepengatahuan di rumah dan masih diakui oleh masyarkat secara Individu.

Etika bisnis sangat penting bagi masyarakat saat ini, untuk memerlukan dan melangsungkan kehidupan yang menghadapi problem saat ini di dunia terutama di dunia bisnis. ${ }^{13}$ Kegiatan ekonomi hendaknya didasari oleh akhlak, sebab akhlak merupakan indikator baik buruknya sebagai pelaku bisnis bagi para usaha untuk mensukseskan atau gagalnya dalam dunia bisnis. Antara pembangunan nilai ekonomis dengan menjaga kelestarian alam atau lingkungan sekitar seperti nilai dua sisi mata uang yang tidka dapat dipisahkan. Pembangunan ekonomi ada sudut nilai positif dna negatif, faktanya dari positif dapat meningkatkan kesjahteraan dan dampak negatif akibat adanya tidka memanfaatkan over exploitation, pencemaran tanah, air, dan udara akibat polusi industri, banjir yang mengakibatkan perubahan iklim.

Pembangunan ekonomi merupakan ranah strategis yang harus senantiasa dibangun dan dikembangkan karena menyangkut hajat hidup orang banyak. Kendatipun demikian, perlu disadari bahwa dengan maraknya pembangunan perekonomian dewasa ini sebagai tuntutan kebutuhan, justru memunculkan masalah yang cukup dilematis, yaitu menyangkut ketidak seimbangan antara pembangunan perekonomian pada satu sisi dan pelestarian alam dan lingkungan di sisi lain. ${ }^{14}$ Fenomena menurunnya kualitas sumber daya alam, terjadinya kerusakan lingkungan secara massif, polusi, banjir dan semakin luasnya lahan kritis, merupakan bukti dari dampak pembangunan ekonomi yang tidak sejalan degan pelestarian alam dan lingkungan. Jika ditinjau dari sudut pandang Islam maka menjaga alam (lingkungan) agar tetap terjaga menjadi keharusan bagi setiap manusia.

\section{KESIMPULAN}

Program PKM pemberdayaan Ibu-ibu Rumah Tangga melalui pelatihan limbah bernilai ekonomis di Rumah Kemasan Kabupaten Purwakarta, merupakan bagian dari kegiatan dosen dan mahasisiwa sebagi bentuk pengabdian pada masyarakat yang bernilai akademisi khusus dibidang ekonomi syariah.

\section{UCAPAN TERIMAKASIH}

Ucapan terimakasish dikhususkan bagi penyelenggara pendidikan Skolah Tinggi Ilmu Ekonomi Syariah Indonesia Purwakarta (STIES), dosen dan mahasiswa yang ikut partisifasi membantu pelatihan di lapangan lapangan dan masyarakat yang terlibat organisasi PKK Purwakarta Kota.

13 Pandji Anaroga, Manajemen Bisnis, (Jakarta: Rineka Cipta: 2009), 75.

14 Bambang Suhada, (Universitas Muhammadiyah Metro) dan Dharma Setyawan, (STAIN Jurai Siwo Metro), Narasi Islam dan Green Economics Kontekstualita, Journal Vol. 31, No.1, 201623

ADINDAMAS (Jurnal Pengabdian Kepada Masyarakat), Volume 1, Nomor 2, Januari 2022 http://journal.sties-purwakarta.ac.id/index.php/adindamas/ ISSN: 2798-2874 (Media Online) 2798-4702 (Media Cetak) 


\section{DAFTAR PUSTAKA}

Afzalur Rahman. Economic Doctrines of Islam. Terj. Soeroyo Nastangin, "Doktrin Ekonomi Islam", Jilid 2. Yogyakarta: Dana Bhakti Wakaf. 1995.

Ali Hasan. Manajemen Bisnis Syari'ah. Yogyakarta: Pustaka Pelajar. 2009.

Artikel ini sudah Terbit di AyoPurwakarta.com, dengan Judul Dedi Mulyadi Ingin Pelopori Persoalan Pencemaran Lingkungan, pada URL.

Bambang Suhada, (Universitas Muhammadiyah Metro) dan Dharma Setyawan, (STAIN Jurai Siwo Metro), Narasi Islam dan Green Economics Kontekstualita, Journal Vol. 31, No.1, 201623

Dosen dan Mahasiswa. Fakultas Hukum. UNPAS. Pemberdayaan Industri Ramah Lingkungan Melalui Program CSR DI Kabupaten Purwakarta dalam Rangka Pengelolaan Limbah B3 Dihubungkan dengan UU No. 40 Tahun 2007, Tentang PT. Jo. UU no. 32 Tahun 2009 Tentang Perlindungan dan Penglolaan Lingkungan Hidup. Hukum Perdata, 2018.

https://gc.ukm.ugm.ac.id/2018/11/ekonomi-kreatif-pemanfaatan-barangbekas/.UGM, 2018.

https://mediaindonesia.com/humaniora/248591/manfaatkan-nilai-ekonomi-dibalik-sampah. 2018.

https://www.ayopurwakarta.com/read/2019/11/29/3689/dedi-mulyadi-inginpelopori-persoalan-pencemaran-lingkungan. 2019.

https://www.detik.com/edu/detikpedia/d-5538767/pengertian-limbahkarakteristik-dan-jenis-jenisnya). Akses 2019.

Lubis, Suhrawardi K. Hukum Ekonomi Islam, Cet. 1. Jakarta: Sinar Grafika. 2000.

Meliandi Purwandito, Eka Mutia dan Ellida Novita Lydia, Pelatihan Pemanfaatan Limbah Plastik Menjadi Produk Bernilai Ekonomis Pada Desa Keumuning Peut. Vol 2 No 2 (2020): Global Science Society (GSS) Jurnal Ilmiah Pengabdian Kepada Masyaraka.

Mulyono Maulid. Menggerakan Ekonomi Kreatif Antara Tuntunan Dan Kebutuhan. Jakarta: Rajawali Pres. 2010.

Pandji Anaroga. Manajemen Bisnis. Jakarta: Rineka Cipta. 2009.

Riany L Nurwulan, dkk. PKM Pemberdayaan Kelompok Pkk Melalui Program Pengelolaan Sampah di Desa Wanayasa Kecamatan Wanayasa Kabupaten Purwakarta, Joernal Universitas Pasundan.

Syafaatul Hidayati. Teori Ekonomi Mikro. Banten: Universitas Pamulang, UNPAM Press. 2019. 